\title{
PENGARUH KOMUNIKASI, MOTIVASI DAN KERJASAMA TIM TERHADAP PENINGKATAN KINERJA KARYAWAN
}

\author{
Eva Silvani Lawasi ${ }^{1}$, Boge Triatmanto ${ }^{1^{*}}$ \\ ${ }^{1}$ Fakultas Ekonomi dan Bisnis, Universitas Merdeka Malang \\ *boge.triatmanto@unmer.ac.id
}

\begin{abstract}
:
The purpose of this study are : (1) to know and analyze the influence of communication, motivation, and team cooperation on employee performance. (2) to know and analyze the variable that has dominant influence to employee performance. The data obtained in this study is the primary data by distributing questionnaires to the respondents. Analyzed data uses multiple linear regression model.. The results of this study proves that, (1) communication has a positive and a significant affect on the improvement of employee performance. (2) Motivation has a positive and a significant affect to the improvement of employee performance. (3) Team cooperation doesn't have a significant affect to the improvement of employee performance and (4) Communication has the dominant influence in improving employee performance.
\end{abstract}

Keywords: Communication, motivation, teamwork, employee performance

\section{PENDAHULUAN}

Mengelola organisasi bukanlah hal yang mudah, sehingga membutuhkan banyak ketrampilan untuk memperlancar pelaksanaannya. Di antara begitu banyak ketrampilan yang dibutuhkan dalam sebuah organisasi, ada satu cara yang dapat menyatukan seluruh aspek untuk bersinergi mencapai tujuan organisasi atau perusahaan, yaitu ketrampilan dan kemampuan dalam berkomunikasi untuk menciptakan suasana berorganisasi yang dapat memotivasi para karyawan memberikan kinerja terbaiknya. Kinerja merupakan hasil pekerjaan yang mempunyai hubungan kuat dengan tujuan strategis organisasi, kepuasan konsumen dan memberikan kontribusi pada ekonomi (Armstrong dan Baron, 1998 :15). Untuk mencapai sebuah kinerja yang baik, juga dibutuhkan ketrampilan komunikasi yang baik. Menurut Muhammad (2002 : 95-196), jenis -jenis komunikasi organisasi antara lain adalah: komunikasi verbal, komunikasi nonverbal, komunikasi interpersonal, komunikasi kelompok kecil, dan komunikasi publik. Komunikasi verbal adalah komunikasi yang menggunakan simbol atau kata-kata, baik yang dinyatakan secara oral atau lisan maupun secara tulisan. Komunikasi nonverbal adalah penciptaan dan pertukaran pesan dengan tidak menggunakan kata-kata seperti: komunikasi yang menggunakan gerakan tubuh, sikap tubuh, vokal yang bukan kata-kata, kontak mata, ekspresi muka, kedekatan jarak dan sentuhan. Komunikasi interpersonal adalah komunikasi dari dalam diri sendiri. Beberapa komponen komunikasi adalah sumber, pesan, saluran penerima dan balikan. Dalam komunikasi interpersonal hanya seorang saja yang terlibat, pesan mulai dan berakhir dalam diri individu masing-masing. Wenburg dan Wilmot (1973) menyatakan bahwa persepsi individu tidak dapat di cek oleh orang lain tetapi semua arti atribut pesan ditentukan oleh individu. Komunikasi kelompok kecil adalah suatu kumpulan individu yang dapat mempengaruhi satu 
sama lain, memperoleh beberapa kepuasan satu sama lain, berinteraksi untuk beberapa tujuan, mengambil peranan, terikat satu sama lain dan berkomunikasi tatap muka. Jika salah satu dari komponen ini hilang individu yang terlibat tidaklah berkomunikasi dalam kelompok kecil. Komunikasi publik adalah pertukaran pesan dengan sejumlah orang yang berada dalam organisasi atau yang diluar organisasi, secara tatap muka atau melalui media.Dalam melakukan sebuah tugas dan pekerjaan, masing-masing individu dituntut untuk memiliki hubungan dan komunikasi yang baik secara menyeluruh baik dari pimpinannya langsung atau pun karyawan. Selain itu, pihak-pihak yang terlibat dalam sebuah perusahaan pasti membutuhkan sebuah informasi apapun mengenai perusahaan tempat dimana mereka bekerja sehingga diperlukan komunikasi yang transparan antara pimpinan dan bawahan yang akan bersama-sama menetapkan tujuan, sasaran dan masa depan perusahaan yang nantinya bisa dicapai bersama. Maka, untuk mencapai tujuan tersebut komunikasi adalah sarana yang tepat untuk mengadakan koordinasi antar masingmasing bidang pekerjaan.

Selain komunikasi, hal lain yang juga akan sangat membantu dan mempengaruhi proses pencapaian tujuan sebuah perusahaan adalah motivasi dan kerjasama tim. Menurut Hasibuan (2001), motivasi adalah bagaimana cara mengarahkan daya dan potensi bawahan agar mau bekerja sama secara produktif. Motivasi juga bisa dikatakan sebagai sebuah dukungan yang didapatkan seorang karyawan dari pimpinan mereka (dari atasan kepada bawahannya) yang nantinya hal ini bisa menjadi pemicu semangat masingmasing karyawan karena merasa dihargai dan diperhatikan sehingga secara tidak langsung akan menimbulkan dan bahkan membangun keinginan masing-masing karyawan untuk terus bekerja dengan giat dan memberikan kontribusi terbaik mereka kepada perusahaan tersebut. Motivasi dalam hal ini tidak berarti harus dalam bentuk materi saja tetapi bisa dalam bentuk penghargaan, pujian dan sejenisnya.
Perhatian kecil yang diberikan oleh seorang pimpinan juga dapat menjadi motivasi untuk karyawannya sehingga mereka mampu meningkatkan kinerja karyawan menjadi lebih baik dari waktu ke waktu.

Selain komuikasi dan motivasi, dalam kehidupan berorganisasi sebuah perusahaan juga membutuhkan kerjasama tim yang solid untuk bisa melengkapi proses pencapaian tujuan perusahaan. Pekerjaan organisasi tidak akan terlaksana jika para anggota organisasi atau perusahaan tidak bekerja sama secara selaras. Kerjasama tim atau tim kerja adalah kelompok yang usahausaha individualnya menghasilkan kinerja lebih tinggi daripada jumlah masukan individual (Stephen dan Timothy, 2008:406). Tim kerja menghasilkan sinergi positif melalui usaha yang terkoordinasi. Hal ini memiliki pengertian bahwa kinerja yang dicapai oleh sebuah tim lebih baik daripada kinerja per individu di suatu organisasi ataupun suatu perusahaan. Walaupun begitu, kerja sama tim juga harus efektif agar memberikan kontribusi yang baik bagi kinerja karyawan dan hasil kerja dalam suatu lembaga.

Menurut Tenner dan Detoro (1992:183), team works is a group of individuals working together to reach a common goal. Definisi kerjasama tim tersebut menjelaskan bahwa kerjasama tim adalah sekelompok orang-orang yang bekerja bersama untuk mencapai tujuan yang sama dan tujuan tersebut akan lebih mudah diperoleh dengan melakukan kerjasama tim daripada dilakukan sendiri. Hal ini diperkuat oleh Gaspersz (2001) bahwa sumber daya manusia pada semua tingkat organisasi merupakan faktor yang sangat penting dari suatu organisasi dan keterlibatan mereka secara penuh akan memungkinkan kemampuan mereka digunakan untuk manfaat organisasi.

Proses meningkatkan kinerja karyawan adalah proses yang sangat penting. Selain untuk keuntungan financial perusahaan, proses-proses tersebut juga sangat penting untuk membangun reputasi baik perusahaan di kalangan masyarakat. 
Kinerja adalah hasil yang dicapai oleh seorang karyawan sesuai dengan tugas dan wewenang pekerjaannya. Salah satu cara untuk mengoptimalkan kinerja karyawan adalah adanya komunikasi efektif di lingkungan perusahaan. Terjalinnya komunikasi yang efektif dapat memunculkan lingkungan kerja yang baik. Karyawan menjadi termotivasi dan dapat bekerja bersama antara pimpinan dan karyawan (tim) dengan baik untuk mencapai kinerja yang optimal. Semakin baik komunikasi yang dibina, maka semakin optimal kinerja karyawan untuk menjalankan tugasnya. Objek Penelitian yang digunakan oleh peneliti adalah Hotel Sahid Montana 1 Malang. Peneliti melakukan penelitian di Hotel Sahid Montana 1 Malang karena peneliti termotivasi untuk mengetahui dan melihat langsung bagaimana kondisi kinerja karyawan yang ada di Hotel Sahid Montana 1 Malang saat ini.

Dilihat dari penelitian terdahulu yang dilakukan oleh Zahiroh, A Umi (2014) dalam judul "Analisis Komunikasi dalam Optimalisasi KinerjaKaryawan Pada Hotel Sahid Montana” yang menyatakan bahwa kualitas karyawan memiliki grooming yang baik dan dapat melayani tamu dengan 4 tahapan berikut: approach, presentation, handeling for section, dan improve self. Hambatan-hambatan komunikasi organisasi di Hotel Sahid Montana dalam rangka optimalisasi kinerja karyawan adalah masalah bahasa, tekanan waktu, dan perbedaan kerangka acuan. Karena dalam penelitian terdahulu peneliti belum menemukan pembahasan mengenai motivasi dan kerjasama tim terhadap peningkatan kinerja karyawan di Hotel Sahid Montana 1 Malang, maka dilakukan penelitian ini dengan judul "Pengaruh Komunikasi, Motivasi, dan Kerjasama Tim Terhadap Peningkatan Kinerja Karyawan di Hotel Sahid Montana 1 Malang”.

Penelitian ini dilakukan dengan tujuan : 1) untuk mengetahui dan menganalisis pengaruh komunikasi, motivasi, dan kerjasama tim terhadap kinerja karyawan, 2) untuk mengetahui variabel yang berpengaruh dominan terhadap kinerja karyawan di Hotel Sahid Montana 1 Malang.

\section{Tinjauan Pustaka \\ Kinerja Karyawan}

Kinerja merupakan hasil pekerjaan yang mempunyai hubungan kuat dengan tujuan strategis organisasi, kepuasan konsumen dan memberikan kontribusi pada ekonomi (Armstrong dan Baron, 1998:15). Kinerja adalah bagaimana melakukan pekerjaan dan hasil yang dicapai dari pekerjaan tersebut. Kinerja dalam organisasi merupakan jawaban dari berhasil atau tidaknya tujuan organisasi yang telah ditetapkan. Pengertian kinerja karyawan menunjuk pada kemampuan karyawan dalam melaksanakan keseluruhan tugas-tugas yang menjadi tanggungjawabnya. Tugas-tugas tersebut biasanya berdasarkan indikatorindikator keberhasilan yang sudah ditetapkan. Sebagai hasilnya akan diketahui bahwa seseorang karyawan masuk dalam tingkatan kinerja tertentu.

Kinerja karyawan dapat dikelompokkan ke dalam tingkatan kinerja tinggi, menengah atau rendah. Selain itu juga dapat dikelompokkan melampaui target, sesuai target atau di bawah target. Kinerja menurut Mangkunegara (2000:67) adalah hasil kerja secara kualitas dan kuantitas terbaik yang dicapai oleh seseorang karyawan dalam pertanggungjawaban penyelesaian tugas yang diberikan kepadanya.

Hasibuan (2001:34) mengemukakan bahwa kinerja adalah pencapaian seseorang dalam melaksanakan segala tanggung jawab yang dibebankan kepadanya yang didasarkan atas kecakapan, pengalaman, dan ketepatan waktu penyelesaian. "Menurut Robert L. Mathis dan John H. Jackson Terjemahan Jimmy Sadeli dan Bayu Prawira (2001:78) menyatakan bahwa kinerja pada dasarnya adalah apa yang dilakukan atau tidak dilakukan karyawan”. Mutu kerja karyawan secara langsung mempengaruhi kinerja perusahaan. Guna mendapatkan kontribusi karyawan yang optimal, manajemen harus memahami secara mendalam strategi untuk 
mengelola, mengukur dan meningkatkan kinerja, yang dimulai terlebih dahulu dengan menentukan tolak ukur kinerja. Ada beberapa syarat tolak ukur kinerja yang baik, yaitu:

1) Tolak ukur yang baik, haruslah mampu dikukur dengan cara yangdapat dipercaya.

2) Tolak ukur yang baik, harus mampu membedakan individu-individusesuai dengan kinerja mereka.

3) Tolak ukur yang baik, harus sensitif terhadap masukan dan tindakan-tindakan dari pemegang jabatan.

4) Tolak ukur yang baik, harus dapat diterima oleh individu yangmengetahui kinerjanya sedang dinilai.

Dari tiga teori yang sudah dijelaskan di atas, dapat disimpulkan bahwa kinerja adalah sebuah pencapaian yang didapatkan atau dihasilkan dari aktivitas karyawan itu sendiri”.

\section{Komunikasi}

Sebuah komunikasi yang efektif menjadi hal yang sangat penting bagi semua organisasi. Untuk memahami komunikasi dengan mudah, perlu diketahui terlebih dahulu mengenai konsep-konsep dasar komunikasi. Menurut Robbins (1996), komunikasi adalah sebuah pengiriman makna kepada orang lain berbentuk lambang, simbol, atau bahasa-bahasa tertentu sehingga orang yang menerima informasi tersebut dapat memahami informasi yang diterimanya.

Menurut Louis Forsdale (1981) "communication is the process by which a system is established, maintained, and altered by means of shared signals what operate according to rules". Komunikasi adalah suatu proses memberikan signal dengan aturan tertentu sehingga dengan cara ini suatu sistem dapat didirikan, dipelihara, dan diubah. Pada definisi ini, komunikasi juga dipandang sebagai suatu proses. Yang dimaksud dengan kata signal disini adalah signal yang berupa verbal dan non verbal yang mempunyai aturan tertentu. Dengan adanya aturan ini menjadikan orang yang menerima signal yang telah mengetahui aturannya akan dapat memahami maksud dari signal yang diterimanya. Misalnya setiap bahasa mempunyai aturan tertentu baik bahasa lisan, bahasa tulisan maupun bahasa isyarat. Bila orang yang mengirim signal menggunakan bahasa yang sama dengan orang yang menerima signal, maka si penerima akan dapat memahami maksud dari signal tersebut, tetapi kalau tidak, mungkin dia tidak dapat memahami maksudnya. Forsdale juga mengatakan bahwa pemberian signal dalam komunikasi dapat dilakukan dengan maksud tertentu atau dengan disadari dan dapat juga terjadi tanpa disadari.

Menurut Brent D. Ruben komunikasi manusia adalah suatu proses dimana hubungan seorang yang satu dan yang lainnya dalam suatu organisasi atau dalam masyarakat menciptakan, mengirimkan serta menggunakan informasi untuk berkoordinasi dengan lingkungan dan sekitarnya. Jika definisi ini dibandingkan dengan dua definisi sebelumnya yang memakai istilah stimulus dan signal, definisi Ruben menggunakan istilah informasi yang diartikan sebagai kumpulan data, pesan (message), susunan isyarat dalam cara tertentu yang mempunyai arti atau berguna bagi sistem tertentu. Istilah menciptakan informasi yang dimaksudkan Ruben adalah tindakan menyandingkan pesan yang berarti kumpulan data atau suatu set isyarat. Sedangkan istilah mengirimkan informasi adalah proses dimana pesan dipindahkan dari si pengirim kepada orang lain. Istilah pemakaian informasi menunjuk kepada peranan informasi dalam mempengaruhi tingkah laku manusia baik secara individual, kelompok, maupun masyarakat. Jadi jelas bahwa tujuan komunikasi menurut ruben adalah untuk mempengaruhi tingkah laku orang lain.

Berdasarkan prinsip umum dari definisi di atas, dapat ditarik kesimpulan bahwa komunikasi adalah proses penyampaian sebuah pesan dalam bentuk atau cara penyampaian yang bisa disesuaikan sehingga makna dari pesan tersebut dapat diterima sehingga terjadi pertukaran pesan verbal maupun non verbal, dan hasil dari 
komunikasi yang telah dilakukan memungkinkan untuk mengubah tingkah laku seseorang (perubahan yang terjadi di dalam diri sesorang).

\section{Motivasi}

Motivasi merupakan satu hal penting yang harus diberikan kepada para karyawan untuk membangkitkan semangat dan gairah bekerja mereka. Berikut adalah bagianbagian yang termasuk dalam sebuah motivasi. "Moekijat (1994:357) mengemukakan bahwa motivasi adalah suatu pengertian yang mengandung semua alat penggerak, alasan-alasan atau dorongan dalam diri manusia yang menyebabkan manusia bertindak" "Menurut M. Manullang (1994 : 145) yang dimaksud dengan motivasi adalah sesuatu yang mendorong manusia untuk bertindak atau suatu tenaga yang ada dalam dirinya yang menyebabkan ia berbuat sesuatu”..

Berdasarkan beberapa definisi yang telah dikemukakan oleh para ahli diatas, maka dapat ditarik kesimpulan bahwa motivasi adalah suatu dukungan yang diberikan kepada seseorang yang menjadi penerima dukungan tersebut sehingga mampu memberikan dorongan kepada orang tersebut untuk melakukan sebuah tindakan dalam mencapai tujuan tertentu.

Menurut Maslow

(1993:92),

kebutuhan manusia adalah sebagai berikut:

1) Kebutuhan fisiologis (physiological), meliputi kebutuhan pangan, pakaian, dan tempat tinggal maupun kebutuhan biologis.

2) Kebutuhan keamanan dan keselamatan (safety), meliputi kebutuhan keamanan kerja, kemerdekaan dari rasa takut ataupun tekanan, keamanan dari kejadian atau lingkungan yang mengancam.

3) Kebutuhan memiliki jiwa sosial dan kasih sayang (social), meliputi kebutuhan terhadap persahabatan, berkeluarga, berkelompok, dan interaksi.

4) Kebutuhan terhadap penghargaan (esteem), meliputi kebutuhan harga diri, status, martabat, kehormatan, dan penghargaan dari pihak lain.

5) Kebutuhan aktualisasi diri (self actualization), meliputi kebutuhan memenuhi keberadaan diri (self fulfillment) dengan memaksimumkan penggunaaan kemampuan dan potensi diri.

\section{Kerjasama Tim}

Tim adalah suatu unit yang terdiri atas dua orang atau lebih yang berinteraksi dan berkoordinasi mengenai sebuah pekerjaan dan upaya-upaya untuk mencapai tujuan tertentu. Kerjasama tim yang baik dibutuhkan untuk bisa mendukung proses pencapaian tujuan perusahaan. "Tracy (2006) menyatakan bahwa teamwork merupakan kegiatan yang dikelola dan dilakukan sekelompok orang yang tergabung dalam satu organisasi. Teamwork dapat membangun kekompakan dalam meningkatkan kinerja karyawan”. "Pernyataan di atas diperkuat Dewi (2007), bahwa kerja tim adalah bentuk kerja dalam kelompok yang harus dikelola dengan baik untuk mencapai sebuah tujuan atau menyelesaikan sebuah tugas”. Stephen dan Timothy (2008) menyatakan bahwa kerja tim adalah kelompok yang usaha-usaha individualnya menghasilkan kinerja lebih tinggi daripada hasil yang didapatkan jika pekerjaan diselesaikan seorang diri. Teamwork menghasilkan sinergi positif melalui usaha yang terkoordinasi. Hal ini memiliki pengertian bahwa kinerja yang dicapai oleh sebuah tim lebih baik daripada kinerja per individu di suatu organisasi ataupun suatu perusahaan.

Dari semua pengertian mengenai Kerjasama tim (teamwork) yang telah dikemukakan, maka dapat ditarik kesimpulan bahwa kerjasama tim merupakan cara paling efektif untuk bisa menyatukan seluruh karyawan dalam melaksanakan tugas-tugas mereka untuk mencapai tujuan perusahaan dengan hasil yang lebih baik. 


\section{Hipotesis}

Hipotesis dalam penelitian ini adalah:

1) Diduga bahwa variabel motivasi, komunikasi dan kerjasama tim berpengaruh positif dan signifikan terhadap kinerja karyawan, 2) Diduga bahwa variabel yang berpengaruh paling dominan terhadap peningkatan kinerja karyawan adalah variabel komunikasi.

\section{METODE}

Komunikasi $\left(\mathrm{X}_{1}\right)$ adalah proses penyampaian sebuah pesan dalam bentuk atau cara penyampaian yang bisa disesuaikan sehingga makna dari pesan tersebut dapat diterima sehingga terjadi pertukaran pesan verbal maupun non verbal, dan hasil dari komunikasi yang telah dilakukan memungkinkan untuk mengubah tingkah laku seseorang (perubahan yang terjadi di dalam diri sesorang). Komunikasi diukur dengan indikator : pemahaman, tindakan, pengaruh pada sikap, dan hubungan yang makin baik (Suranto,2010:105).

Motivasi $\left(\mathrm{X}_{2}\right)$ adalah suatu dukungan yang diberikan kepada seseorang yang menjadi penerima dukungan tersebut sehingga mampu memberikan dorongan kepada orang tersebut untuk melakukan sebuah tindakan dalam mencapai tujuan tertentu. Motivasi diukur dengan indikator kebutuhan fisiologis, kebutuhan keamanan dan keselataman, kebutuhan rasa memiliki jiwa sosial dan kasih sayang, kebutuhan terhadap penghargaan, dan kebutuhan aktualisasi diri (Maslow,1993:92).

Kerjasam tim $\left(\mathrm{X}_{3}\right)$ merupakan cara paling efektif untuk bisa menyatukan seluruh karyawan dalam melaksanakan tugas-tugas mereka untuk mencapai tujuan perusahaan dengan hasil yang lebih baik. Kerjasama tim diukur dengan indikator kerjasama, kepercayaan, kekompakan (West, 2002),

Kinerja karyawan (Y) adalah sebuah pencapaian yang didapatkan atau dihasilkan dari aktivitas karyawan itu sendiri. Kinerja karyawan diukur dengan indikator kualitas karyawan, kuantitas karyawan, ketepatan waktu (Dharma, 2005 :50).
Dalam penelitian ini yang menjadi populasi adalah karyawan tetap dari Hotel Sahid Montana 1 Malang. Jumlah karyawan tetap yang ada di Hotel Sahid Montana 1 Malang adalah 48 orang. Menurut Arikunto (1998 : 120), bahwa apabila subyeknya kurang dari 100 orang lebih baik diambil seluruhnya sebagai sampelnya. Dengan dasar pendapat tersebut diatas maka sampel penelitian ini adalah seluruh anggota populasi sebesar 48 orang (metode sensus).

Model analisis yang digunakan adalah Regresi Linier Berganda untuk mengetahui pengaruh variabel bebas terhadap variabel terikat. Adapun persamaan Regresi Linier Berganda adalah sebagai berikut.

$\mathrm{Y}=\alpha+\mathrm{b}_{1} \mathrm{X}_{1}+\mathrm{b}_{2} \mathrm{X}_{2}+\mathrm{b}_{3} \mathrm{X}_{3}+\mathrm{e}$

Keterangan :

$\mathrm{X}_{1} \quad$ : Komunikasi

$\mathrm{X}_{2} \quad$ : Motivasi

$\mathrm{X}_{3} \quad$ : Kerjasama Tim,

$\mathrm{Y} \quad$ : Kinerja Karyawan,

$\alpha \quad$ : Koefisien Intersep (Konstanta)

b : Koefisiensi Regresi

e : Kesalahan Pengguna

\section{HASIL}

Regresi Linier Berganda digunakan untuk mengetahui pengaruh variabel bebas terhadap variabel terikat. Hasil Analisis Regresi Linier adalah sebagai berikut:

Tabel 1. Hasil Regresi Linier Berganda

\begin{tabular}{lcccc}
\hline Variabel & $\begin{array}{c}\text { Koef. } \\
\text { Regresi }\end{array}$ & $\begin{array}{c}\text { Std. } \\
\text { Error }\end{array}$ & t & Sig \\
\hline Konstanta & $-0,034$ & 0,821 & $-0,041$ & 0,967 \\
Komunikasi & 0,331 & 0,135 & 2,457 & 0,018 \\
Motivasi & 0,359 & 0,177 & 2,027 & 0,049 \\
Kerjasama & 0,292 & 0,149 & 1,956 & 0,057 \\
Tim & & & & \\
R & & 0,602 & & \\
R-Squared & & 0,362 & & \\
Adj R- & & 0,319 & & \\
Squared & & & & \\
F Hitung & & 8,329 & & \\
Sig. & & 0,000 & & \\
\hline
\end{tabular}

Sumber : data diolah

Hasil pengolahan data untuk Regresi Linier Berganda dengan menggunakan 
program SPSS 20.0 dapat dilihat pada tabel 1. Hasil Regresi Linier Berganda. Dari tabel tersebut dapat disusun persamaan regresi linier berganda seperti berikut :

$Y=-0,034+0,331 X_{1}+0,359 X_{2}-292 X_{3}$

Berdasarkan persamaan regresi linier berganda di atas dapat diuraikan sebagai berikut :

1) Nilai konstanta sebesar -0,034, menunjukkan bahwa apabila tidak ada variabel komunikasi, motivasi, dan kerjasama tim maka kinerja karyawan akan menurun.

2) Koefisien regresi variabel komunikasi $\left(b_{1}\right)$ bernilai positif sebesar 0,331, menunjukkan bahwa jika komunikasi meningkat satu persen maka akan terjadi peningkatan kinerja karyawan sebesar $33,1 \%$, dimana variabel motivasi dan kerjasama tim dianggap tetap.

3) Koefisien regresi variabel motivasi $\left(b_{2}\right)$ bernilai positif sebesar 0,359, menunjukkan bahwa jika variabel motivasi meningkat satu persen maka akan terjadi peningkatan kinerja karyawan sebesar 35,9\%, dimana variabel komunikasi dan kerjasama tim dianggap tetap.

4) Koefisien regresi variabel kerjasama tim $\left(b_{3}\right)$ bernilai positif sebesar 0,292, menunjukkan bahwa jika variabel kerjasama tim meningkat satu persen maka akan terjadi peningkatan kinerja karyawan sebesar 29,2\%, dimana variabel komunikasi dan motivasi dianggap tetap.

5) Nilai Adjusted R-Squared adalah sebesar 0,319 atau sebesar 31,9\%. Hal inimenunjukkan bahwa pengaruh variabel Komunikasi (X1), Motivasi (X2), dan Kerjasama Tim (X3) terhadap Kinerja Karyawan (Y) hanya sebesar $31,9 \%$ dan sisanya sebesar $68,1 \%$ dipengaruhi oleh faktor lain.

\section{Analisis Hipotesis}

Berdasarkan hasil uji statistik Regresi Linier pada tabel 1 di atas dapat dilihat bahwa didapatkan hasil secara simultanF sebesar 8,329 dan hasil Sig 0,000 yang menunjukkan bahwa variabel komunikasi (X1), motivasi (X2), dan kerjasama tim (X3) berpengaruh secara simultan atau bersamasama terhadap kinerja karyawan (Y). Maka untuk hipotesis pertama yang menyatakan bahwa terdapat pengaruh antara variabel komunikasi, motivasi dan kerjasama tim terhadap kinerja karyawan diterima.

Untuk hasil analisis secara parsial (t) didapatkan hasil untuk variabel komunikasi $\left(\mathrm{X}_{1}\right)$ dengan nilai 0,018 , variabel motivasi $\left(\mathrm{X}_{2}\right)$ dengan nilai 0,049 dan variabel kerjasamat Tim $\left(\mathrm{X}_{3}\right)$ dengan nilai 0,057 dimana hasil ini menunjukan bahwa untuk variabel $\mathrm{X}_{1}$ dan variabel $\mathrm{X}_{2}$ dinyatakan signifikan, sedangkan hasil untuk variabel $\mathrm{X}_{3}$ menyatakan bahwa hasilnya tidak signifikan. Namun, diantara variabel komunikasi $\left(\mathrm{X}_{1}\right)$ dan variabel motivasi $\left(\mathrm{X}_{2}\right)$ yang memiliki pengaruh paling dominan terhadap peningkatan kinerja karyawan (Y) adalah variabel komunikasi dengan nilai 0,018. Maka untuk hipotesis kedua yang menyatakan bahwa variabel komunikasi memiliki pengaruh paling dminan dapat diterima.

\section{PEMBAHASAN}

Proses komunikasi yang efektif akan memberikan dampak positif bagi pelaku komunikasi tersebut, misalnya munculnya pemahaman, keinginan untuk melakukan sebuah tindakan, pengaruh yang terjadi pada sikap, dan hubungan yang terjalin antar individu pun semakin baik, sama halnya dengan apa yang saat ini terjadi. Pengukuran yang dilakukan untuk mengetahui proses komunikasi ini pun dengan menggunakan 4 indikator yang terdiri dari pemahaman, tindakan, pengaruh pada sikap dan hubungan yang makin baik. Hasil penelitian menunjukkan bahwa proses komunikasi yang saat ini diterapkan memberikan pengaruh yang besar pada sikap karyawan dan hubungan antar karyawan serta hubungan 
antara karyawan dan pimpinan, bisa dikatakan bahwa dampak dari komunikasi ini membuat hubungan masing-masing individu menjadi semakin baik. Ini berarti bahwa komunikasi memiliki pengaruh terhadap peningkatan kinerja karyawan yang ada, karena semakin baik komunikasi yang dilakukan oleh pihak perusahaan, maka dampak positif pun akan semakin meluas bagi karyawan yang nantinya bisa mempengaruhi kinerja masing-masing karyawan. Hasil penelitian ini sejalan dengan penelitian terdahulu milik Dimas Okta Ardiansyah pada tahun 2016 menyatakan bahwa komunikasi berpengaruh signifikan dan positif terhadap kepuasan kerja atau kinerja karyawan. Hasil penelitian ini juga didukung dengan teori Hariandja (2002 : 96) bahwa komunikasi merupakan bagian yang penting dalam kehidupan kerja, sehingga hal ini mudah dipahami sebab komunikasi yang tidak baik bisa mempunyai dampak yang luas terhadap kehidupan organisasi, misalnya konflik antar karyawan, kesenjangan karyawan dan begitupun sebaliknya.

Persepsi tentang motivasi dibentuk oleh kebutuhan fisiologis, kebutuhan keamanan dan keselamatan, kebutuhan memiliki jiwa sosial dan kasih sayang, Kebutuhan terhadap penghargaan, dan kebutuhan aktualisasi diri. Motivasi adalah sebuah keinginan atau dorongan yang berasal dari dalam diri individu untuk kemudian melakukan suatu tindakan yang dianggapnya sesuai dengan situasi yang dia alami. Hasil penelitian yang dilakukan terhadap karyawan yang ada menunjukkan bahwa para karyawan ini ingin membutuhkan ruang untuk mengaktualisasikan diri atau dengan kata lain kebutuhan untuk mendapatkan pengakuan. Kinerja mereka akan semakin baik ketika mereka merasa termotivasi melalui perhatian dan penghargaan yang diberikan oleh pimpinannya. Ini berarti bahwa Motivasi berpengaruh terhadap peningkatan kinerja karyawan. Hasil dari penelitian ini sejalan dengan penelitian terdahulu milik Windy (2009) yang membuktikan bahwa motivasi kerja berpengaruh signifikan dan positif terhadap kinerja karyawan. Dan Hasil penelitian ini juga didukung dengan teori Moekijat (1994:357) yang mengemukakan bahwa motivasi adalah suatu pengertian yang mengandung semua alat penggerak, alasanalasan, atau dorongan dalam diri manusia yang menyebabkan manusia itu bertindak.

Kerjasama tim dalam penelitian ini diukur melalui indikator kerjasama, kepercayaan dan kekompakkan. Penelitian yang dilakukan mengenai kerjasama tim yang ada di perusahaan tersebut menunjukkan hasil bahwa indikator kepercayaan merupakan pembentuk utama kerjasama tim dibandingkan dengan kerjasama dan kekompakkan. Kepercayaan membuat masing-masing individu yakin bahwa orang-orang disekitarnya mampu bekerja secara tim. Ditinjau pula dengan hasil analisis Regresi Linier Berganda yang membuktikan bahwa kerjasama tim tidak berpengaruh signifikan, namun hasil perhitungan ini hanya selisih beberapa angka saja, dimana dapat disimpulkan bahwa sebenarnya Kerjasama tim juga memiliki pengaruh terhadap peningkatan kinerja karyawan tapi tidak lebih besar dari pengaruh yang diberikan oleh komunikasi dan motivasi.

\section{Kesimpulan}

Komunikasi berpengaruh positif dan signifikan terhadap peningkatan kinerja karyawan. Hal ini dibuktikan karena hasil penelitian menyatakan bahwa proses komunikasi yang saat ini diterapkan telah memberikan dampak positif bagi karyawannya, yaitu perubahan sikap ke arah yang lebih baik dan juga hubungan antar karyawan, karyawan dan pimpinan yang semakin membaik pula.

Motivasi berpengaruh positif dan signifikan terhadap peningkatan kinerja karyawan. Hal ini dibuktikan karena hasil penelitian menyatakan bahwa pemberian motivasi dengan tepat akan membentuk pola pikir karyawan untuk bertindak dan melakukan sesuatu yang sesuai dengan kondisi perusahaan. Pemberian motivasi pun 
juga bisa mendorong karyawan untuk meningkatkan kinerja mereka.

Kerjasama tim tidak berpengaruh signifikan terhadap peningkatan kinerja karyawan. Hal ini dibuktikan dari hasil penelitian yang menunjukkan bahwa variabel yang memberikan pengaruh pada kinerja karyawan adalah komunikasi dan motivasi. Kerjasama tim dibangun oleh kepercayaan. Semakin tinggi rasa percaya antar karyawan maka semakin baik pula kerjasama tim sehingga akan memberikan pengaruh terhadap kinerja karyawan.

Berdasar hasil penelitian mengenai uji Analisis Regresi Linier Berganda, maka dapat diketahui bahwa variabel yang berpengaruh dominan dalam meningkatkan kinerja karyawan adalah variabel komunikasi. Komunikasi memang sangat penting dalam kehidupan sehari-hari, apalagi bagi organisasi, karena dengan komunikasi yang efektif mampu menyatukan pemikiranpemikiran individu dalam organisasi.

\section{Saran}

Disarankan untuk bisa melatih dan meningkatkan kerjasama tim bagi seluruh karyawan sehingga ketika komunikasi dan motivasi disandingkan dengan kerjasama tim antar karyawan maka kinerja karyawan pun akan semakin baik dan meningkat. Mengingat penelitian ini masih memiliki kekurangan, maka bagi peneliti selanjutnya dapat melakukan penelitian lebih lanjut pada perusahaan jasa atau perhotelan yang lain dengan menggunakan sampel yang lebih besar dari sampel yang peneliti gunakan dalam penelitian ini. Disamping itu juga bagi peneliti selanjutnya dapat menambahkan variabel independen lainnya dalam rangka meningkatkan kinerja karyawan, misalnya variabel kepemimpinan, variabel lingkungan dan variabel pengembangan karir.

\section{DAFTAR PUSTAKA}

Ancok D. 1995. Validitas dan Reliabilitas Instrumen Penelitian. Di dalam: Metode Penelitian Survai. Ed Revisi (Editor: Masri Singarimbun dan SofianEffendi), LP3ES, Jakarta
Arikunto. 2006. Penelitian Suatu Pendekatan Praktik., Rineka Aksara, Jakarta

Armstrong M, Baron A. 1998.Developing Practice Performance Management. British: Institute of Personnel Development.

Arikunto, Suharsimi. 1998. Prosedur Penelitian. Rineka Cipta, Jakarta.

Ardiansyah, Dimas Okta. Pengaruh Komunikasi Terhadap Kinerja Karyawan Dengan Dimediasi Oleh Kepuasan Kerja (Studi Pada Bagian Produksi Pabrik Kertas PT Setia Kawan Makmur Sejahtera Tulungagung). 2016. Jurnal Bisnis dan Manajemen Vol. 3 No.1. Universitas Brawijaya.

Brent D.Ruben dan Lea P.Stewar. 2013. Komunikasi dan Perilaku Manusia., Rajawali Pers., Jakarta

Burhan Nurgiyantoro dkk. 2004. Statistik Terapan untuk Penelitian IlmuIlmuSosial, Gadjah Mada University Pers, Yogyakarta

Dharma, Surya. 2005. Manajemen Kinerja. Pustaka Pelajar. Jakarta.

Forsdale, L. 2001. Perspectives on Communication. Canada : McGrawHill College.

Ghozali, Imam. 2005. Analisis Multivariate dengan Program SPSS, Badan Penerbit Universitas Diponegoro, Semarang

Gaspersz, Vincent. 2001. Total Quality Management. Gramedia Pustaka Utama, Jakarta.

Hasibuan, Malayu S.P. 2001. Organisasi dan Motivasi: Dasar Peningkatan Produktivitas. Bumi Aksara, Jakarta 
Hutasuhut, Harry Wijaya. 2011. Analisis Tim Kerja Karyawan Pada PT. Buana Varia Komputama Site Medan. Skripsi. Universitas Sumatera Utara, Medan

Imeldi, Maria. 2010. Analisa Pengaruh Motivasi Kerja, Pelatihan, Kepemimpinan, Komunikasi dan Kerjasama Tim Terhadap Kinerja Suster Dina ST. Yoseph di Indonesia. Jurnal Program Magister Manajemen Ekonomi dan Bisnis. Universitas Sam Ratulangi, Manado

Kholifah. 2011. Pengaruh Motivasi dan Lingkungan Kerja Terhadap Kinerja Pegawai Pada Kantor Kecamatan Kanigaran Kota Probolinggo. Tesis. Universitas Merdeka Malang, Malang

Laksono, Ambar Prambudy. 2015. Pengaruh Komunikasi dan Budaya Organisasi Terhadap Kinerja Pegawai Pada Unit Pelaksana Teknis Pelatihan Kerja Kediri Disnaker Transduk Provinsi Jawa Timur. Tesis. Malang :Universitas Merdeka Malang.

M, Iman. (trans). Aw, Suranto. 2010.IlmuMaslow AH, Motivasi dan Kepribadian 1. PT. Remaja Bandung, Bandung.

Mangkunegara, Anwar Prabu. 2000. Manajemen Sumber Daya Manusia Perusahaan. Rosdakarya, Bandung

Marsanto. 2013. Pengaruh Kepemimpinan, Komunikasi dan Motivasi Terhadap Kinerja Aparatur Pemerintah Desa di Kecamatan Siman Kab. Ponorogo. Tesis, Universitas Merdeka Malang, Malang

Mathis, Robert L. dan John H. Jakcson, 2002. Manajemen Sumber Daya Manusia.Salemba Empat. Jakarta.
Moekijat. 1994. Manajemen Kepegawaian. Cetakan ke-5. Ghalia Indonesia. Jakarta.

Rahmawaty, Penny. 2012. Pengertian Model Motivasi.diunduh dari : http://www.academia.edu/6422976/Pen gertian_Motivasi_2._Model_Motivasi_ 3._Teori_Motivasi

Riani, Asri Laksmi. 2011. Perspektif Kompensasi Untuk Menilai Kinerja., Yuma Pustaka, Surakarta

Riniwati, Harsuko. 2011. Mendongkrak Motivasi dan Kinerja-Pendekatan Pemberdayaan SDM, Universitas Brawijaya, Malang

Robbins, Stephen P. dan Timothy A. Judge. 2008.Perilaku Organisasi Edisi ke-12, Salemba Empat, Jakarta

Santoso, Singgih. 2000. SPSS Statistik Parametrik. PT. Elex Media Komputindo. Jakarta.

Schuler dan Jackson. 1996.Manajemen Sumber DayaManusia. Erlangga. Jakarta.

Sugiyono. 2005. Statistika untuk Penelitian. Alfabeta, Bandung

Suharto dan Budi Cahyono. 2005, Pengaruh Budaya Organisasi, Kepemimpinan dan Motivasi Kerja Terhadap Kinerja Sumber Daya Manusia, di sekretariat DPRD Propinsi Jawa Tengah. JRBI. Vol. 1, No.1, januari 2005: 13-30.

Tenner, A.R. dan DeToro, I.J. 1992. Total Quality Management : Three Stepps To Continuous Improvement. Reading, MA: Addison-Wesley Publishing Company.

Windy, Mg, Marischa. 2009. Analisis Pengaruh Motivasi Kerja, Kemampuan Kerja dan Komitmen Organisasi 
terhadap Kinerja Karyawan (Studi pada PT. Wahana Sun Motor Semarang). Tesis. Unisbank, Semarang

Wenburg, Jhon R dan William W. Wilmot. 1973. The Personal Communication Process”. Wiley, New York

Zahiroh, Aisa Umi. 2014. Analisis Komunikasi dalam Optimalisasi Kinerja Karyawan Pada Hotel Sahid Montana. Jurusan Manajemen, Fakultas Ekonomi, Universitas Negeri Malang, Malang 